\title{
APPLICATION OF IS-MP-IA MODEL AND TAYLOR RULE TO CESEE ECONOMIES
}

\author{
Dushko Josheski ${ }^{1}$, Dimitar Eftimoski ${ }^{2}$ \\ ${ }^{1}$ University Goce Delcev Stip, Macedonia, dushkojosheski@gmail.com \\ ${ }^{2}$ St. Clement of Ohrid University of Bitola, Macedonia,dimitar@ukim.edu.mk
}

\begin{abstract}
In this paper, the extended framework of the IS-MP-IA model has been tested. Since the appearance of the Romer's (2000) model, a bulk of studies with its extensions have been published. Perhaps, the most notable amongst them were those proposed by Hsing $(2004,2013)$ and Giese and Wagner $(2006)$ - which are integral part of this paper. The application of the extended Romer (2000) model to selected Central Eastern and South Eastern Europe (CESEE) countries (Albania, Bulgaria, Croatia, Czech Republic, Estonia, Hungary, Macedonia, Moldova, Romania, Russian Federation, Slovak Republic, Slovenia and Ukraine) shows that on an average, higher world output and lower world interest rate and inflation have positive effect on real output. A lower government consumption to gross domestic product (GDP) ratio also increases the real output. However, the insignificant government consumption implies that the Ricardian equivalence might hold in these economies. Hence, fiscal prudence is needed, and the conventional approach of real currency depreciation, in order to stimulate exports and raise real output, is not recommendable for the selected CESEE countries. The results from this paper can be useful for the policymakers and the academia. They prove the theoretical and empirical value of the Romer's IS-MP-IA model. From a methodological point of view, we use generalised method of moments (GMM) estimator for dynamic panel data models, that is, first-differenced GMM.
\end{abstract}

Keywords: extended IS-MP-IA, Taylor rule, inflation targeting, monetary policy function, Ricardian equivalence, first-differenced GMM.

Type of the paper: Empirical study.

JEL Classification: E52, E62, F41.

\section{Introduction}

The aim of the research is to investigate the relevance of the Romer's (2000) IS-MP-IA model on a panel of countries from Central Eastern and South Eastern Europe (CESEE): Albania, Bulgaria, Croatia, Czech Republic, Estonia, Hungary, Macedonia, Moldova, Romania, Russian Federation, Slovak Republic, Slovenia and Ukraine, for the time period 1993-2013.

As noted in the predictions of the theoretical model, the hypotheses are set as follows: First, the higher world output, lower world interest rate and lower expected inflation positively affect the output of the countries in the sample. Second, the conventional approach of real currency depreciation does not hold for the sampled countries. In order to test these hypotheses, an econometric technique is being used.

We are starting with some specifics of the countries encompassed in our panel:

Albania in the previous two decades achieved macroeconomic stability, fiscal discipline and public debt reduction (Shijaku, Gjokuta 2013). Public debt, as percentage of gross domestic product (GDP), has shown declining from $35 \%$ in 1990 s to $29 \%$ in 2010 . Since July 1992, in order to avoid costly adjustments for possible exchange rate misalignments that characterise pegged exchange rate regimes, Albania has adopted free-floating exchange rate regime (Ljuci, Vika 2011).

During the referenced period, Bulgaria has experienced macroeconomic imbalances especially related with the high stock of external liabilities and weak labour markets (European Commission, Bulgaria 2014). After crisis, the growth in this country has remained low and Bulgaria has experienced slow 
recovery. Inflation rate has remained low, too. Some studies about the effectiveness of fiscal policy in Bulgaria showed low fiscal multiplier, which does not exceed 0.4 points (Markova, Deyanov 2013). Bulgarian currency is pegged to euro, and fixed exchange rate regime is being practiced.

Croatia has been mired in recession since 2009 (European Commission, Croatia 2014). In the period 2009-2014, the Croatian GDP has been reduced by $12 \%$, and only in the past two years very slow recovery had happened. The decline in real GDP was induced by the sharp decline in domestic investments, particularly in construction industry. Unemployment rate in 2013 was above $17 \%$ (almost twofold increase since 2008). Pro-cyclical fiscal policies in 'boom years' were followed by loose policies, when the economy was facing downturn. The nominal debt also has increased and had reached $64.9 \%$ of GDP at the end of 2013. Unlike Bulgaria, fiscal policy elasticities have reached higher magnitudes, but an increase in government spending has resulted with crowding-out effect in the majority of Croatian industries (Tkalec, Vizek 2009). Since 1994, Croatia has been in a system of de facto currency board with quasi-fixed exchange rate.

In the past two decades in the Czech Republic, certain macroeconomic improvements have been made. The expansion of the monetary and fiscal policy has increased the inflow of foreign direct investment, which contributed to the dynamics of economic growth (Czesaný 2010). After years of fiscal loosening, debt had realised an upward trend from 18\% of GDP in 2000 to $29 \%$ in 2004. In 2012, public debt in Czech Republic had reached almost 45\% of GDP. It has been followed by structural consolidation and substantial economic reforms (IMF, Czech Republic 2013). Since 1994, Czech Republic adopted floating exchange rate regime. As of 1997, inflation targeting framework, when managing exchange rate, has been adopted in Czech Republic.

Estonia has joined euro in January 2011. The budget deficit in 2013 was very low (1\% of GDP), but the unemployment rate (especially in the long term) has remained high and with an upward trend. Estonia had 'recorded' problem only with the inflation rate, which, in accordance to Maastricht criteria, should have been no more than 1.5 percentage points above the average rate of the three EU member states with the lowest inflation over the previous year (Kopicka et al. 2007).

Hungary has experienced double dip recession in 2012. GDP growth has returned positive after one year later, but still the recovery seems to be very slow (in the post-recession period, GDP growth is estimated to 1.1\%) (European Commission, Hungary 2014). Public debt is high but steady, and it accounts $80 \%$ of the Hungarian GDP. The official currency is pegged to euro as an anchor (crawling band), and the currency target zone is $\pm 15 \%$ (Ibolya 2003 ).

Macroeconomic policy in Macedonia aims at achieving long-term sustainable growth, increasing the competitiveness of the economy and employment (Ministry of finance of the Republic of Macedonia 2015). Global economic crisis in Macedonia was reflected in 2009, primarily through the fall in exports. Budget deficit is held on a moderate level of $2.7 \%$ of GDP (Ministry of finance of the Republic of Macedonia 2011), but after a period of loosened fiscal policy, it has been expanded to $4.2 \%$ of GDP in 2013. Public debt is around 34\% of GDP in 2014 and exhibits an upward trend. Macedonia has adopted fixed exchange rate regime.

According to IMF (IMF, Moldova 2014), in 2014, Moldova had achieved fiscal consolidation. However, the need for structural reforms is still being strongly emphasised. The overall budget deficit has been reduced from $8.4 \%$ of GDP in 2009 to $3.9 \%$ in 2012, but in 2014, it deteriorated by increasing to $5.5 \%$ of Moldavian GDP. Inflation is in the target range, which is accomplished by a successful monetary policy. Economic activity in Moldova rose by $8.9 \%$ in 2013, but afterwards, the economy experienced deceleration in the economic rise by $2.25 \%$. Moldova tries to maintain low inflation and a flexible exchange rate regime.

In Romania, before the economic crises, high rates of economic growth were recorded. Then, this country has experienced a sharp growth decline with negative rates. In 2009, mostly because of the fall of investment, the economic growth reached $-5 \%$. After 2011, the Romanian economy recovered from the recession but the growth rates remained relatively low (around 3\% annually) (European Commission, Romania 2015). Before and during the crisis, Romania had budget deficit of $8 \%$ of GDP, but in the past couple of years (up to the 2014), it succeed to manage to 1.8\% of GDP. In 2012, public 
debt was $37.3 \%$ of GDP. The exchange rate regime of the national currency is a managed float, accompanied with an inflation targeting - as a nominal anchor of the monetary policy.

In Russia, high economic growth rates were recorded in the period 1999-2006 (average growth rate reached 6.7\%), (Ignatiev 2007). In 2005 and 2006, Russia had experienced a significant amount of budget surplus - by $7.5 \%$ and $7.4 \%$, respectively. According to official Russian statistics, the federal budget deficit was $8 \%$ in 1993. In 1998, Russia entered into the financial crisis. This crisis followed the Asian financial crisis from 1997. In august 1998, Russian national currency was devalued, and Russian government floated the exchange rate. Also during this period, Russian government defaulted on the domestic debt. Chronic tax shortfall led to increased borrowing requirements (Mcauley 2000). Government debt from 1995 to 1998 rose from 50\% to 75\% from GDP. Also the decrease in oil and non-ferrous metal prices influenced Russian economy with heavily deep negative impact. The unemployment rate has reached its peak in 2003, and the level was $8.6 \%$. During the start of the global financial crisis 2007-2008, Russia's unemployment rate was $6.1 \%$ and $6.3 \%$, respectively. Russia in 2014 ended dollar/euro currency peg and adopted free-float regime.

The recent global and financial crisis has caused Slovakia, similar to many transition countries, to suffer declining economic activities. Slovak share index had declined by $56.7 \%$ from 2008 to 2010 (Hsing 2013). In 2006, public debt as percentage of GDP was 38.2\%, fiscal deficit was 3.0\%, inflation was $3.6 \%$ and long-term interest rate was $3.5 \%$ (Festic, Romih 2008). Slovakia had approached ERM II in November 2005 (any currency in ERM II is allowed to float within a range of $\pm 15 \%$ with respect to a central rate against the euro). From 2002 to 2014, Slovakia had recorded average economic growth of $4.3 \%$. Average inflation for the same period was around $3 \%$, whilst the average unemployment rate was $11.8 \%$. Current account deficit peaked at 7\% of GDP in 2008.

The biggest decline in Slovenian real GDP was recorded in 2009 ( $-7.9 \%$ in comparison to 2008). Also negative growth rates were recorded in $2012(-2.5 \%), 2013(-1.6 \%)$ and $2014(-0.1 \%)$ (European Commission 2014). The debt to GDP ratio in Slovenia rose from 22\% in 2008 to $54 \%$ in 2012. Since January 2007, Slovenia issues its own euro coins, like other countries in the Euro-zone. Slovenia has adopted free-floating exchange rate regime.

Ukraine suffered a mild recession in 1999 , when industrial production growth fell by $0.2 \%$ and rose to $12.4 \%$ in 2004 . In the same period, consolidated budget balance gradually had increased from $-1.5 \%$ to $-3.1 \%$, and the inflation fell from $19.2 \%$ to $12.3 \%$. Unemployment rate was $8.6 \%$ in 2004 (Aslund 2005). In Ukraine, still unresolved conflict (in Eastern Ukraine from the end of January 2014) had taken its toll in terms of industrial production and financial markets. The large exchange rate depreciation since early 2014 raised public debt to GDP ratio (Lagarde 2015) and provoked contraction to economic activity (which has been estimated to 6.9\% in 2014). In order to support gradual fiscal and external sustainability, IMF has proposed flexible exchange rate regime for this country.

The results obtained from the country-specific data prove the theoretical and empirical value of the Romer's IS-MP-IA model for the selected CESEE economies.

\section{Literature review}

Hicks, who himself developed the model in 1937, offered an explanation to the problem of combining $I S$ with $L M$ curve. However, the mainstream $I S-L M$ model has been a subject of criticism for many years, especially when combined with the $A D-A S$ model - which links the aggregate demand to price level.

In the spirit of modern macroeconomics, which requires a link between demand, output and inflation rate, Romer (2000) has proposed the $I S-M P$ - IA model, in which the basic feature was the replacement of the LM curve with the interest rate, imposed by the Central Bank.

Bofinger, Mayer and Wollmerhäuser's (2006) paper develops more comprehensive framework in terms of the supply side. This paper introduces monetary policy rules (e.g. Taylor Rule) as well as the Central Bank credibility issue. 
In Carlin and Soskice (2006), the treatment of the interest rate is close to the one proposed by Woodword (2003). Monetary policy, in this paper, is modelled as a monetary rule, $I S$ curve remains as in the conventional IS-MP-IA model, but Romer's 'inflation adjustment' is replaced by an 'inertiaaugmented Phillips curve'. The inertia-augmented Philips curve derives from a combination of Calvo pricing and monopolistic competition.

Giese and Wagner (2006) paper also discusses the IS-MP-IA model and its application in the modern macroeconomic analysis, putting special emphasise on the impact of supply and demand shocks. More precisely, Giese and Wagner used graphical analysis framework for the new neoclassical synthesis to explain and interpret the behaviour of the new neoclassical model under shocks.

Finally, the extensions of Romer (2000) model have been made by Hsing $(2004,2013)$ and Hsing and Hsieh (2009). Some ideas and modifications of these extensions are applied in this paper. By applying the Romer's (2000) IS-MP-IA model, along with its Hsing (2004), Hsing and Hsieh (2009) and Giese and Wagner (2006) extensions, we are trying to understand the fundamental macroeconomic relationships in CESEE countries.

\section{Methodology}

The baseline $I S-M P-I A$ model is presented by the following three equations (this is a slightly different version than the one proposed by Giese and Wagner (2006). The only difference appears in the $I S$ relation, where an income shock is introduced):

$$
\begin{aligned}
& I S: y_{i t}=y_{i, t+1}-a_{1}\left(r_{i t}-r_{i t}^{*}\right)+\eta_{i t} \\
& M P: r_{i t}=r_{i 0}+\sigma_{1} \pi_{i t}+\sigma_{2}\left(y_{i t}-y_{i}^{*}\right) \\
& I A: \pi_{i t}=\beta \pi_{i, t+1}+\varphi\left(y_{i t}-y_{i}^{*}\right)+\varepsilon_{i t}
\end{aligned}
$$

where $I S$ represents investment-saving relation, $M P$ denotes monetary policy and $I A$ is inflation adjustment. In the previous three identities, the following rules apply: $a_{1}>0 ; \sigma_{1,2}>0 ; \varphi>0$, discount factor $0<\beta<1$. In the $I A$ identity, $\varepsilon_{i t}$ is the inflationary shock. In the $I S$ identity, $r_{i t}^{*}$ is the equilibrium interest rate, whilst $\eta_{i t}$ represents an income shock. In the $M P$ identity, $r_{i 0}$ is the interest rate at the beginning of the period. In all three identities, $y_{i t}$ denotes the level of output, $r_{i t}$ is the real interest rate, $\pi_{i t}$ is the inflation and $y_{i t}^{*}$ is the natural level of output achieved without 'sticky prices'. If we simplify and assume that the aggregate expenditures are equal to the output, we get

$$
y_{i t}=\mathrm{E}\left(y_{i t}, r_{i t}, g_{i t}, \tau_{i t}\right)
$$

In the previous identity, $r_{i t}=\left(i_{i t}-\pi_{i t}{ }^{*}\right)$ represents the real interest rate - where $i_{i t}$ is a nominal interest rate and $\pi_{i t}^{*}$ is expected inflation $-g_{i t}$ represents government consumption, $\tau_{i t}$ represents taxes and $\mathrm{E}$ is the expected value of the variables in brackets.

In the literature, the augmentation of the Romer (2000) model was presented in the work of Hsing and Hsieh (2009), in which the applied extended monetary policy function follows this interest rate rule:

$$
r_{i t}=r\left(\pi_{i t}-\pi_{i t}^{*}, y_{i t}-y_{i}^{*}, e_{i t}-e_{i t}^{*}, r^{w}\right)
$$

where $r^{w}$ represents world interest rate, $e_{i t}$ represents real effective exchange rate and $e_{i t}^{*}$ is the expected real effective exchange rate.

For the inflation adjustment, Hsing and Hsieh (2009) proposed the following identity:

$$
\pi_{i t}=\pi_{i t}^{*}+\alpha\left(y_{i t}-y_{i}^{*}\right)+e^{\text {nominal }}+\varepsilon_{i t}
$$

where $e^{\text {nominal }}$ is the nominal effective exchange rate and $\varepsilon_{i t}$ is the inflationary shock. The inflationary shock can be put in terms of target inflation rates. Hence, if Central Bank chooses lower inflation target, $\pi_{i 1}<\pi_{i 0}^{*}$, this sets inflationary shock to be $\varepsilon_{i t}=-(\alpha-1)\left(\pi_{i 1}-\pi_{i 0}^{*}\right)$. 
In addition, variable that augments the Romer (2000) model is the real effective exchange rate:

$$
e_{i t}=f\left(r_{i t}-r^{w}, e_{i t}^{*}\right)
$$

Furthermore, it is well known that the Central Banks are, in general, risk averse. Therefore, when deriving the monetary policy rule, they include in the function a risk aversion towards inflation, and try to maximise (Carlin, Soskice 2005):

$$
L=\frac{1}{2}\left[\left(y_{i t}-y_{i}^{*}\right)^{2}+\beta\left(\pi_{i t}-\pi_{i t}^{*}\right)^{2}\right]
$$

subject to the Philips curve: $\pi_{i t}=\pi_{i, t-1}+\alpha\left(y_{i t}-y_{i}^{*}\right)$.

The monetary policy rule here is set as

$$
y_{i t}-y_{i}^{*}=-\alpha \beta\left(\pi_{i t}-\pi_{i t}^{*}\right)
$$

Previous expression implies that the slope of monetary policy rule curve is $\gamma=\frac{1}{\alpha \beta}$, which reflects both, the slope of the Philips curve as well as the inflation aversion of Central Banks. Now, following Carlin and Soskice (2005), in its Taylor Rule form, the monetary policy rule becomes

$$
\left.r_{i 0}-r_{i t}^{*}=\frac{1}{(\alpha+\gamma) a}\left[\left(\pi_{i t}-\pi_{i t}^{*}\right)\right)+\alpha\left(y_{i t}-y_{i}^{*}\right)\right]
$$

where $r_{i 0}$ is the interest rate at the beginning of the period, whilst $r_{i t}^{*}$ is the equilibrium interest rate, that is, the equilibrium interest rate on a short term. Here, the Central Bank inflation aversion is reflected through the coefficient $\frac{1}{(\alpha+\gamma) a}$. In the Taylor rule, the weights on the two deviations are equal to 0.5 , which are set empirically on the basis of the behaviour of the US Federal Reserve.

\section{Econometric model and results}

Following Patra and Kapur (2010) and Goodhart and Hofman (2005), we use generalised method of moments (GMM) methodology. The first-differenced, that is, Arellano-Bond (A-B) dynamic GMM model that is applied in this paper takes the following form:

$$
\begin{gathered}
\log y_{i t}=\beta_{0}+\beta_{1} \log y_{i, t-1}+\beta_{2} \log y_{i, t}^{w}+\beta_{3} \log r_{i, t}^{w}+\beta_{4} \log c_{i t}+\beta_{5} \log g_{i t}+ \\
+\beta_{6} \log e_{i t}+\beta_{7} \log \pi_{i t}+\beta_{8} \log p_{i t}+\beta_{9} \log k_{i t}+u_{i t}
\end{gathered}
$$

where

$\log y_{i t}$ is the logarithm of real output (in billions of US dollars $2005=100$ );

$\log _{i t}$ is the logarithm of government consumption (in billions US dollars $2005=100$ );

$\log y_{i, t}^{w}$ is the logarithm of world output;

$\log e_{i t}$ is the logarithm of exchange rate; when lagged once, this represents expected inflation, that is, expected real effective exchange rate;

$\log r_{i, t}^{w}$ is the logarithm of world interest rate (US Federal funds rate is subtracted by the Producer Price Index (PPI) in US manufacturing, which proxies for US inflation);

$\log \pi_{i t}$ is the logarithm of inflation; when lagged once, this represents expected inflation;

$\log c_{i t}$ is the $\operatorname{logarithm}$ of household consumption (in billions US dollars $2005=100$ );

$\log p_{i t}$ is the logarithm of population (in thousands);

$\log k_{i t}$ is the logarithm of physical capital (in billions US dollars $2005=100$ )

$u_{i t}$ is the error term

Here, $u_{i t}=v_{i}+\varepsilon_{i t}$. To remove the fixed effects $v_{i}$, we use the following first-differenced algebraic transformation: 
$\Delta u_{i t}=\Delta v_{i}+\Delta \varepsilon_{i t}$ so $u_{i t}-u_{i, t-1}=\left(v_{i}-v_{i}\right)+\left(\varepsilon_{i, t}-\varepsilon_{i, t-1}\right)=\varepsilon_{i, t}-\varepsilon_{i, t-1}$

In general, with the predetermined regressors, one can set the following instruments matrix:

$$
W_{i}=\left(\begin{array}{ccc}
y_{i 1}, x_{i 1}^{\prime}, x^{\prime}{ }_{i 2} & \ldots & 0 \\
\vdots & y_{i 1}, y_{i 2}, x_{i 1}^{\prime}, x^{\prime}{ }_{i 2}, x^{\prime}{ }_{i 3} & \vdots \\
0 & \ldots & y_{i 1 . .,}, y_{i, t-2}, \ldots, x_{i 1}^{\prime} \ldots, x_{i, t-1}^{\prime}
\end{array}\right)
$$

where $W$ is the matrix that contains all instruments of a country $i$.

Validity of the instruments is proven using the Sargan test of over-identifying restrictions, where the null hypothesis is that the over-identified restrictions are valid. As an addition, the A-B test of autocorrelation, which examines the hypothesis that there is no second-order autocorrelation in the first-differenced residuals, is applied.

The sample for the regressions includes two periods: from 1993 to 2003 and from 2004 to 2013. The reason behind this sample division is to account for transition and post-socialist period, immanent for most of the countries in the sample. The second sub-sample, from 2004 to 2013, is used to take into account the economic crises that started in 2008 and was ongoing to 2013, as well as to take into account the macroeconomic policies that were adopted by these countries during their European Union integration. We use data from the Penn World Tables and the World Bank.

Table 1. Two sample regression models (First-differenced GMM approach) (Source: author's estimation)

\begin{tabular}{|c|c|c|c|c|c|c|c|c|}
\hline \multicolumn{5}{|c|}{ Regression for the time period 1993-2003 } & \multicolumn{4}{|c|}{ Regression for the time period 2004-2013 } \\
\hline & Coefficient & p-value & Coefficient & p-value & Coefficient & p-value & Coefficient & p-value \\
\hline $\begin{array}{l}\text { Log of real GDP } \\
\text { lagged once }\end{array}$ & 0.040 & 0.079 & 0.055 & 0.007 & 0.014 & 0.465 & -0.006 & 0.775 \\
\hline $\begin{array}{l}\text { Log of world } \\
\text { output level }\end{array}$ & 1.114 & 0.000 & 0.496 & 0.000 & 0.971 & 0.000 & 0.726 & 0.000 \\
\hline $\begin{array}{l}\text { World interest } \\
\text { rate }\end{array}$ & -0.003 & 0.002 & -0.001 & 0.012 & -0.002 & 0.259 & -0.001 & 0.300 \\
\hline $\begin{array}{l}\text { Government } \\
\text { consumption }\end{array}$ & -0.021 & 0.020 & -0.014 & 0.196 & -0.007 & 0.550 & -0.004 & 0.755 \\
\hline $\begin{array}{l}\text { Household } \\
\text { consumption }\end{array}$ & & & 0.507 & 0.000 & & & 0.284 & 0.002 \\
\hline $\begin{array}{l}\text { Log of expected } \\
\text { exchange rate }\end{array}$ & 0.108 & 0.072 & 0.100 & 0.070 & 0.215 & 0.019 & 0.144 & 0.033 \\
\hline $\begin{array}{l}\text { Log of expected } \\
\text { inflation }\end{array}$ & -0.065 & 0.000 & -0.046 & 0.000 & -0.062 & 0.004 & -0.059 & 0.001 \\
\hline Log of population & -1.499 & 0.000 & -1.035 & 0.012 & -2.137 & 0.000 & -1.771 & 0.000 \\
\hline $\begin{array}{l}\text { Gross capital } \\
\text { formation level }\end{array}$ & $6.12 \mathrm{E}-13$ & 0.000 & $-7.9 \mathrm{E}-14$ & 0.735 & $1.17 \mathrm{E}-13$ & 0.003 & $1.87 \mathrm{E}-13$ & 0.635 \\
\hline Constant & 20.5 & 0.000 & 15.8 & 0.015 & 31.8 & 0.000 & 26.92 & 0.000 \\
\hline (A-B) test order 1 & $z=-2.2747$ & 0.023 & $z=-2.1894$ & 0.029 & $z=-2.6684$ & 0.008 & $z=-2.6685$ & 0.008 \\
\hline (A-B) test order 2 & $z=-0.3439$ & 0.731 & $\mathrm{z}=-1.0753$ & 0.282 & $z=1.3999$ & 0.162 & $\mathrm{z}=1.4000$ & 0162 \\
\hline Sargan test & $\chi 2(44)=45.48$ & 0.410 & $\chi 2(44)=47.73$ & 0.324 & $\chi 2(35)=44.43$ & 0.1318 & $\chi 2(35)=37.10$ & 0.372 \\
\hline Number of panels & 13 & & 13 & & 13 & & 13 & \\
\hline $\begin{array}{l}\text { Number of } \\
\text { observations }\end{array}$ & 88 & & 88 & & 77 & & 78 & \\
\hline $\begin{array}{l}\text { Observations per } \\
\text { panel (average) }\end{array}$ & 6.84 & & 6.67 & & 5.92 & & 5.92 & \\
\hline $\begin{array}{l}\text { Number of } \\
\text { instruments }\end{array}$ & 53 & & 54 & & 44 & & 45 & \\
\hline
\end{tabular}

Note: The estimation method is panel first-differenced generalised method of moments (GMM), with robust standard errors - White period weights from final iteration. Dependent variable: Logarithm of real GDP 
From Table 1, one can see that the world output is positive and significant when related to the logarithm of output of the countries in the sample. World interest rate is negatively and significantly associated with the output in the first sub-sample from 1994 to 2003 but is negative and insignificant in the second sub-sample from 2003 to 2013, which might be result of the financial and economic crises, when the monetary policy is, in general, ineffective. Expected inflation is negative and significant in all models, whilst the expected exchange rate is positively and significantly associated with the output of the countries. This proves that the conventional wisdom to pursue currency depreciation to stimulate the economy may not work for the CESEE countries. Government consumption is negative and significant in the period 1993-2003. This can be indicator for the need of fiscal austerity. However, when the household consumption is included, the coefficient of government consumption becomes insignificant, which proves that the Ricardian equivalence may be applicable (We assume that the debt is zero, and all the government consumption is financed through taxes). In the second sub-sample, the coefficient of the government consumption variable becomes insignificant, which is further proving of possible applicability of the Ricardian equivalence to this set of countries. The sign of population variable, which is used as a proxy for a country size, is negative and significant, whilst the sign on gross-capital formation is positive and significant, which is not a case when the household consumption variable is included.

Basically, our findings hold important implications for policymaking in CESEE countries. First, the negative effect of a higher expected inflation rate on real output indicates that the Central Banks of CESEE countries should continue to focus on maintaining price stability. Second, the estimated negative coefficient of fiscal policy (proxy variable is government consumption expenditure) confirms fiscal policy ineffectiveness. The relatively small size of the government spending multiplier suggests that the governments should place little reliance on the use of expansionary fiscal policy. Third, the depreciation of the real effective exchange rates of the countries in the sample is not a good strategy. Real effective exchange rate appreciation on a contrary proves to be better recommendation for policymakers in these set of countries. Of course, these economies cannot influence the world output, as well as the world interest rate, but both variables do have significant effect on their output.

Finally, it can be useful to mention that the desired conditions of the A-B test of autocorrelation are satisfied. More precisely, in the A-B test of autocorrelation of order $1, z$ values must be negative, that is, $<0$, and statistically significant. In the test for the second order of the autocorrelation, $z$-score should be positive, that is, $z>0$, and it must be insignificant. On the other hand, the Sargan test proves that one cannot reject the null hypothesis that over-identifying restrictions are valid, which proves the validity of instruments. This is supported with the high p-values reported in the results for the test.

\section{Conclusion}

This paper has applied the extended IS-MP-IA model to investigate possible impacts of changes in exogenous variables on CESEE economies, with a real effective exchange rate taken into account. This is important because countries in the sample have different exchange rate regimes, so it seems that weighted average of the value of country's currency relative to the currencies of their biggest trading partners is far better solution. Yet currency depreciation is not suitable policy for the two separate time periods (from 1993 to 2003 and from 2004 to 2013). In the period of economic crisis, turns out that currency depreciation might produce contractionary effects.

Empirical results show that on an average, lower expected inflation rate, lower government consumption, depreciation of the currencies, lower federal funds rate and greater world output is expected to increase output in the CESEE economies. An extended Romer (2000) model showed that an increase in the household consumption, on an average, would lead to higher output. Also, population reduction is positively associated with the increase in output, as well as the increase in the employment-to-population ratio. The importance of gross capital formation is especially emphasised in the periods of economic crises. Therefore, we can conclude that the augmented IS-MP-IA model which takes into account international trade in the IS function, the world interest rate in the MP 
function and the exchange rate in the IA function - enables one to better understand macroeconomic relationships that influence CESEE economies.

\section{References}

Arellano, M., \& Bond, S. (1991). Some tests of specification for panel data: Monte Carlo evidence and an application to employment equations. The Review of Economic Studies, 58, 277 - 297.

Aslund, A. (2005). The Economic Policy of Ukraine after the Orange Revolution, Eurasian Geography and Economics, 46, No. 5, Copyright V. H. Winston \& Son, Inc, 327-353.

Carlin, W., \& Soskice, D. (2005). The 3-Equation New Keynesian Model-a Graphical Exposition, CEPR, Duke University, LSE and Wissenschaftszentrum Berlin, Macroeconomics: Imperfections, Institutions, and Policies (2005), Oxford University Press, 2006

Czesaný, S. (2010). The business cycle in the Czech Republic: trends, context and economic policy implications. Ekonomické rozhlady/Economic review, Volume, 39./2010.

European Commission. (2014). Macroeconomic imbalances in Bulgaria 2014, Occasional Papers 173.

European Commission. (2014). Macroeconomic imbalances in Croatia 2014, Occasional Papers 179.

European Commission. (2014). Macroeconomic imbalances in Hungary 2014, Occasional Papers 180.

European Commission, (2014). Macroeconomic imbalances in Slovenia 2014, Occasional Papers 187.

European Commission, (2015). Macroeconomic imbalances in Romania 2015, Occasional Papers 223.

Festic, M., \& Romih, D. (2008). Cyclicality of the banking sector performance and macro environment in the Czech Republic, Slovakia and Slovenia. Prague economic papers, Vol.17 No. 2.pp. 99-117

Giese, G., and Wagner, H. (2006). Graphical Analysis of the New Neoclassical Synthesis. Available at SSRN: http://ssrn.com/abstract $=958382$ or http://dx.doi.org/10.2139/ssrn.958382

Goodhart, C., \& Hofmann, B. (2005). The IS Curve and Transmission of Monetary Policy: Is there a Puzzle? Applied Economics, Vol.37, 29-36.

Hisng, Yu. (2004). Extension of Romer's IS-MP-IA model to small open economies. Atlantic Economic Journal, September 2004, Volume 32, Issue 3, p. 257-257.

Hsing, Yu. (2013). Impacts of macroeconomic variables on the stock market in Slovakia and policy implications. Economics \& Economy, Vol. 1, No. 1 (March, 2013), 7-16.

Hsing, Yu., and Hsieh, W. (2009). Response of output in Romania to macroeconomic policies and conditions, Preliminary paper.

Ibolya, M. (2003). Exchange rate policy of Hungary on the way to European Union membership, Universität Duisburg-Essen (Standort Duisburg), dissertation.

Ignatiev, S. (2007). The macroeconomic situation and monetary policy in Russia, Speech by Dr Sergey Ignatiev, Chairman of the Central Bank of the Russian Federation, at the 2007 Money and Banking Conference "Monetary Policy Under Uncertainty", hosted by the Central Bank of Argentina, Buenos Aires, 4 June 2007.

IMF. (2013). Czech Republic 2013 article iv consultation, IMF Country Report No.13/243.

IMF. (2014). Moldova 2014 article iv consultation and first post-program monitoring discussions-staff report; press release; and statement by the executive director for the republic of Moldova, IMF Country Report No. $14 / 190$.

Kopicka, J., Parimbekov, A., \& Roth, V. (2007). Estonia: An Economy in Transition, Working paper, University of Michigan.

Lagarde, C. (2015). Ukraine: letter of intent, memorandum of economic and financial policies, and technical memorandum of understanding. IMF.

Ljuci, E., \& Vika, I. (2011). The equilibrium real exchange rate of lek vis à vis euro: Is it much misaligned?, Bank of Greece discussion papers.

Markova, K.., Deyanov, G., \& Iliev,V. (2013). Fiscal policy and economic growth in Bulgaria. NBRM second research conference, April 2013. 
Mcauley, A. (2000). What were the causes of the Russian financial crisis of 1998? What role did the IMF play in solving the problem? University of Essex economics department, UK Essays. November 2013. The Russian Financial Crisis. [online]. [Accessed 15 March 2016]. Available from:

http://www.ukessays.com/essays/economics/the-russian-financial-crisis.php?cref=1

National economic reform programme, (2015), Ministry of finance of the Republic of Macedonia.

Patra, M., D., \& Kapur, M. (2010). A monetary policy model without money for India, IMF Working Paper, $10 / 183$.

Pre-accession economic programme. (2011). Macroeconomic policy, public finance and structural reforms, Ministry of finance of the Republic of Macedonia.

Romer, D. (2000). Keynesian macroeconomics without the LM curve, Journal of Economic Perspectives, Volume14, Number 2, Spring 2000: 149.

Shijaku, G., \& Gjokuta, A. (2013). Fiscal policy and economic growth: The case of Albania, Bank of Albania.

Tkalec, M., \& Vizek, M. (2009). The Impact of Macroeconomic Policies on Manufacturing Production in Croatia, Institute of Economics - Zagreb, Research Paper. 